OPEN ACCESS

Edited by:

Yixian Wang

Hefei University of Technology, China

Reviewed by:

Dongfang Liang,

University of Cambridge,

United Kingdom

Kang Peng,

Chongqing University, China

${ }^{*}$ Correspondence:

Rui Chen

cechenrui@hit.edu.cn

Specialty section: This article was submitted to Earth and Planetary Materials,

a section of the journal

Frontiers in Earth Science

Received: 14 December 2019

Accepted: 14 May 2020

Published: 16 June 2020

Citation:

Deng G, Zhang L-L, Chen R, Liu L,

Shu K-X and Zhou Z-L (2020)

Experimental Investigation on

Suffusion Characteristics of Cohesionless Soils Along Horizontal Seepage Flow Under Controlled Vertical Stress.

Front. Earth Sci. 8:195 doi: 10.3389/feart.2020.00195

\section{Experimental Investigation on Suffusion Characteristics of Cohesionless Soils Along Horizontal Seepage Flow Under Controlled Vertical Stress}

\author{
Gang Deng ${ }^{1}$, Liang-Liang Zhang ${ }^{2}$, Rui Chen ${ }^{2 *}$, Lei-lei Liu ${ }^{2}$, Kai-Xiang Shu ${ }^{2}$ and \\ Zhi-Le Zhou ${ }^{2}$
}

${ }^{1}$ State Key Laboratory of Simulation and Regulation of Water Cycle in River Basin, China Institute of Water Resources and Hydropower Research, Beijing, China, ${ }^{2}$ Department of Civil and Environmental Engineering, Harbin Institute of Technology, University Town of Shenzhen, Shenzhen, China

Suffusion is one of the main modes of internal erosion leading to selective erosion and gradual migration of fine soil particles through the voids of soil skeleton formed by coarse soil particles under seepage flow. Suffusion may induce deterioration and even failure of hydraulic geo-structures, such as embankment dams, dikes, levees, as well as landslide dams, if they are formed by gap-graded cohesionless soils. Soil mass in the hydraulic geo-structures is always subjected to overburden load and seepage through the soil mass generally has a large component along the horizontal direction. In the literature, however, little attention has been paid to the horizontal seepage-induced suffusion under controlled vertical stress. In this study, horizontal seepage-induced suffusion tests were carried out using a testing apparatus with controllable vertical stress and hydraulic gradient. The seepage flux and eroded fine particle mass, as well as local hydraulic gradients can be measured. The effects of initial dry density and initial fines content on suffusion characteristics of a cohesionless soil were investigated. Test results showed that after the initiation of suffusion, alternate decrease, and increase in the coefficient of permeability occurred possibly due to alternate clogging and dredging of soil pores by the movable fine particles. Uneven distribution of local hydraulic gradients along the flow path was observed and this could be regarded as a sign of the initiation of suffusion. Both initiation and failure hydraulic gradients increased with initial dry density and initial fines content.

Keywords: gap-graded cohesionless soil, horizontal seepage flow, suffusion, dry density, fines content, vertical stress

\section{INTRODUCTION}

Suffusion is one of the main modes of internal erosion leading to selective erosion and gradual migration of fine particles through the voids of soil skeleton formed by coarse particles under seepage flow. Seepage-induced suffusion is widely observed in hydraulic geo-structures, including embankment dams, dikes, levees, as well as landslide dams, and natural deposits 
(Foster et al., 2000; Fell et al., 2003; Xu and Zhang, 2009; Chang et al., 2011; Zhang et al., 2011; Peng and Zhang, 2012; Wang et al., 2019; Yang et al., 2019; Yuan et al., 2019a, 2020; Kang et al., 2020; Peng et al., 2020a). For a soil susceptible to suffusion, its hydraulic properties may change accordingly after some fine particles within the soil are eroded and migrated (Ke and Takahashi, 2012; Horikoshi and Takahashi, 2015; Sato and Kuwano, 2015; Yuan et al., 2019b). Hence, suffusion may lead to deterioration and even catastrophic failure of the hydraulic geo-structures which were formed by gap-graded cohesionless soils (Foster et al., 2000; Moffat and Fannin, 2006; Moffat et al., 2011; Ke and Takahashi, 2012; Peng et al., 2020b). Suffusion of gap-graded cohesionless soils has drawn the special attention of many researchers such as Kenney and Lau (1985), Skempton and Brogan (1994), Wan and Fell (2008), Indraratna et al. (2011, 2015), Wang et al. (2014), and Ouyang and Takahashi (2015), Marot et al. (2016), Mehdizadeh et al. (2017), and Zhong et al. (2018).

Skempton and Brogan (1994) found that the failure hydraulic gradient of suffusion in a sandy gravel was far lower than that given by the classical theory. The possible reason was that the major part of overburden load was carried by the soil skeleton formed by gravel particles, while the sand particles were less involved in the load transfer chains. Subsequently, many experimental investigations on suffusion have been carried out by various researchers. The investigations showed that the parameters affecting suffusion characteristics included particle size distribution of soils (Kenney and Lau, 1985; Indraratna et al., 2011, 2015; Chang and Zhang, 2013; Moraci et al., 2014), hydraulic gradient (Salehi Sadaghiani and Witt, 2011; Ke and Takahashi, 2012; Song et al., 2018), seepage flow direction (Richards and Reddy, 2012; Hosseini and Pachideh, 2018), hydraulic loading history (Luo et al., 2013a; Rochim et al., 2017), fines content (FC, i.e., the mass ratio of fine particles to total weight of the soil specimen; Ke and Takahashi, 2012, 2014; Ouyang and Takahashi, 2015) and others. In most of these investigations, the suffusion tests were along vertical seepage flow without consideration of external stress. However, in engineering practice, soil mass in hydraulic geo-structures is always subjected to overburden load and seepage through the soil mass generally has a large component along the horizontal direction. Recently, the influence of stress on suffusion behavior has received ever more attention (Bendahmane et al., 2008; Chang and Zhang, 2011, 2012; Luo et al., 2013a, 2017, 2019; Zou et al., 2013; Liang et al., 2017, 2019; Peng et al., 2019a,b, 2020c; Zhao et al., 2019). Experimental investigations showed the initiation and failure hydraulic gradients were significantly affected by stress states. It should be noted that in most of these investigations, the seepage direction was still vertical, which is largely different from that in engineering practice. As suggested by Richards and Reddy (2012), Zou et al. (2013), and Hosseini and Pachideh (2018), the suffusion behavior was significantly affected by the direction of seepage flow. Hence, it is necessary to carry out experimental investigations on the horizontal seepage-induced suffusion under controlled vertical stress.

The primary purpose of this study is to investigate the characteristics of the horizontal seepage-induced suffusion in gap-graded cohesionless soils under controlled vertical stress. Suffusion tests along horizontal seepage flow were carried out using a testing apparatus with controllable vertical stress and hydraulic gradient. Local hydraulic gradients, as well as the seepage flux and eroded fine particle mass were measured. The effects of initial dry density and initial fines content on suffusion characteristics of a cohesionless soil were investigated.

\section{APPARATUS, MATERIALS, AND METHODOLOGY}

\section{Test Apparatus}

A testing apparatus newly developed by the authors (Deng et al., 2017) was used in this study. As shown in Figure 1, it mainly consists of a horizontal seepage system, a vertical load applying system, a pressurized water supply system, a soil-water collection system and a data acquisition system.

The main component of the horizontal seepage system is the permeameter chamber, which can accommodate a soil specimen of $300 \mathrm{~mm}$ in length, $285 \mathrm{~mm}$ in width, and $300 \mathrm{~mm}$ in height. The vertical load applying system includes a pressure source, a pressure bladder, and a pressure regulator. The applied vertical stress ranges from 5 to $600 \mathrm{kPa}$ with an accuracy of $0.4 \%$ full scale (FS). The hydraulic gradient is applied by controlling water pressures at both water-inlet and water-outlet. Generally, the pressure at the water-outlet is kept at the atmospheric pressure. The pressure at water-inlet is controlled by a system which consists of an air compressor, a reducing valve and a gas-liquid exchange tank. The maximum applied water pressure can be up to $150 \mathrm{kPa}$ with an accuracy of $0.2 \mathrm{kPa}$. The accumulative weight of eroded fine particles is monitored using the soil-water collection system. Nine pore water pressure transducers (PWPs) are used to measure the pore water pressure distribution within the soil specimen as shown in Figure 1B. The measurement range of PWP is from -100 to $200 \mathrm{kPa}$ with an accuracy of $\pm 0.2 \%$ FS. Hence, local hydraulic gradients can be obtained from the measurements of PWP at different locations in the soil specimen. All transducers are connected to the data acquisition system. For more details about this apparatus, please refer to Deng et al. (2017).

\section{Test Materials}

Artificial gap-graded soils were used in this study. The soils were the binary mixtures of two quartz sands with different mixing ratios. The particle size distribution curves of the three mixtures and two quartz sands are shown in Figure 2, in which the curve of the coarse sand is denoted as " $\mathrm{C}$," whereas the fine one as "F." The " $\mathrm{C}$ " sand has a particle size range from 1.18 to $3.35 \mathrm{~mm}$, which is regarded as the soil-skeleton particle for the mixture. The "F" sand has a particle size range from 0.106 to $0.212 \mathrm{~mm}$, which is considered as the erodible fine particles through the voids of the skeleton formed by the coarse particles. According to the Unified Soil Classification System (ASTM D287-11, 2012), the two sands are classified as poorly graded sands (SP). The physical properties of the soils are summarized in Table 1. According to the geometric criteria proposed by 

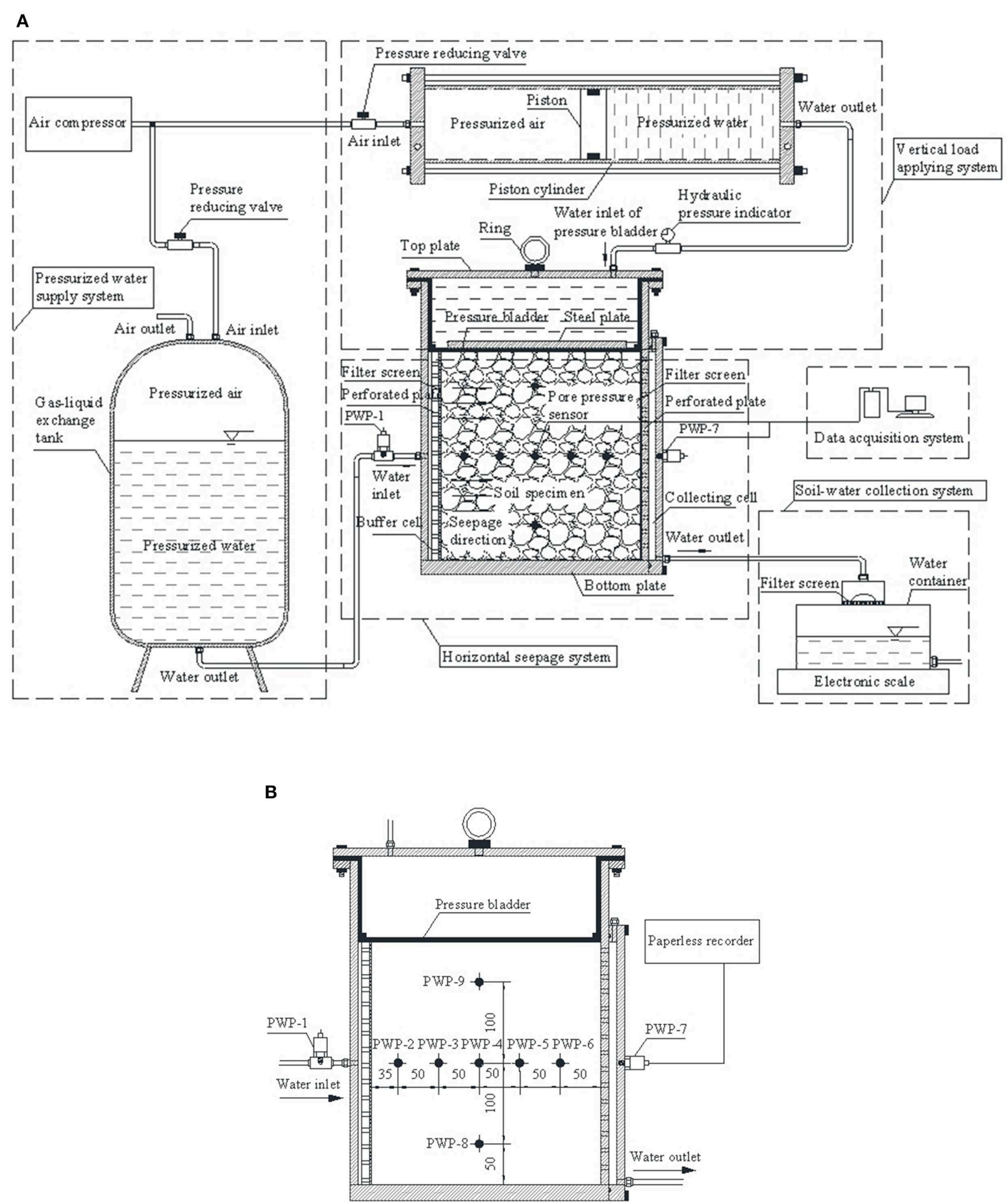

FIGURE 1 | Schematic illustration of the testing apparatus: (A) the layout of the testing system (B) the layout of pore water pressure transducers.

Kenney and Lau (1985), Kenney et al. (1985), Moffat and Fannin (2006), and Indraratna et al. (2011), the three mixtures were internally unstable. In other words, suffusion might occur in these soils.

\section{Test Program}

Two series of tests were performed in this study. The first series was to investigate the effect of initial dry density $\left(\rho_{\mathrm{d}}\right)$ on the horizontal seepage-induced suffusion behavior. As shown in 


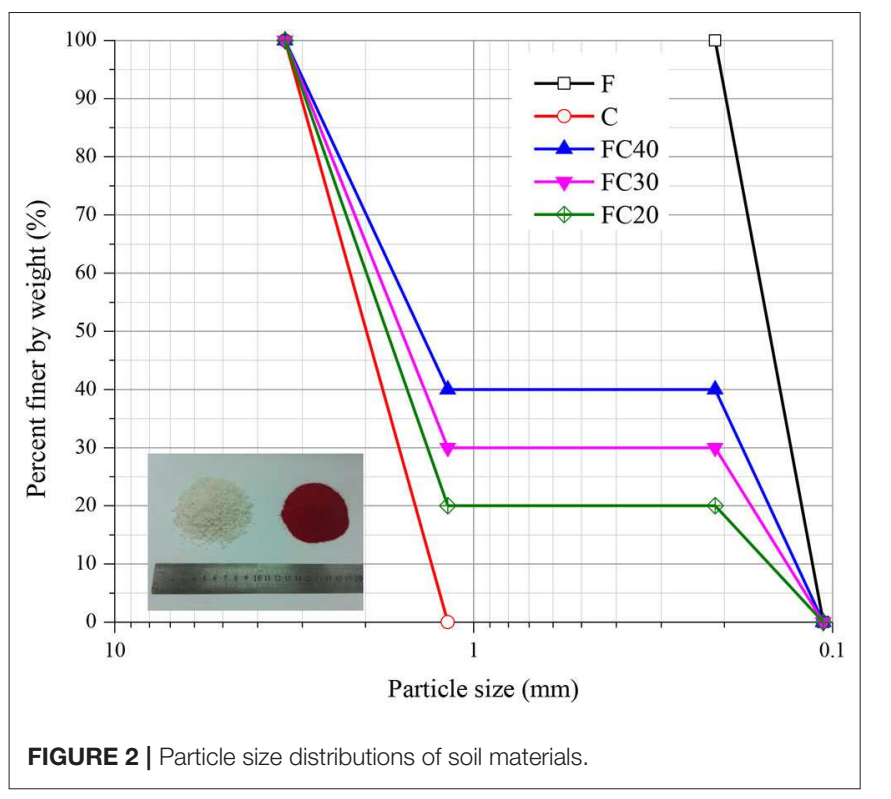

TABLE 1 | Physical properties of soils tested in this study.

\begin{tabular}{lccccc}
\hline Physical property & Sand $\boldsymbol{F}$ & Sand $\boldsymbol{C}$ & Mixture & Mixture & Mixture \\
\cline { 4 - 6 } & & & FC20 & FC30 & FC40 \\
\hline FC (\%) & 100 & 0 & 20 & 30 & 40 \\
$\begin{array}{l}\text { Specific gravity, Gs } \\
\text { Effective particle size, }\end{array}$ & 2.65 & 2.65 & 2.65 & 2.65 & 2.65 \\
$d_{10}(\mathrm{~mm})$ & 0.11 & 1.31 & 0.15 & 0.13 & 0.12 \\
$\begin{array}{l}\text { Median particle size, } \\
d_{30} \text { (mm) }\end{array}$ & 0.13 & 1.62 & 1.34 & 0.21 & 0.18 \\
$\begin{array}{l}\text { Mean particle size, } \\
d_{50} \text { (mm) }\end{array}$ & 0.15 & 2.01 & 1.75 & 1.60 & 1.43 \\
$\begin{array}{l}\text { Constrained particle } \\
\text { size, } d_{60} \text { (mm) }\end{array}$ & 0.16 & 2.20 & 2.01 & 1.84 & 1.67 \\
$\begin{array}{l}\text { Coefficient of } \\
\text { uniformity, Cu }\end{array}$ & 1.4 & 1.7 & 13.4 & 14.2 & 13.9 \\
$\begin{array}{l}\text { Coefficient of } \\
\text { curvature, Cc }\end{array}$ & 1.0 & 0.91 & 6.0 & 0.2 & 0.2 \\
\hline
\end{tabular}

Table 2, three values of dry density were considered in the first series (i.e., 1.6, 1.7, and $1.8 \mathrm{~g} / \mathrm{cm}^{3}$ ). In this series, the initial FC was $40 \%$. By referring the one with the dry density of $1.7 \mathrm{~g} / \mathrm{cm}^{3}$ in the first series, two more values of FC (i.e., 20 and $40 \%$ ), were considered in the second series to study the effect of FC on suffusion behavior. All tests were subjected to a vertical stress of $300 \mathrm{kPa}$ to simulate the overburden pressure.

\section{Test Procedure}

The test process mainly included four stages: (1) preparation of soil specimen, (2) saturation of specimen, (3) application of vertical load and consolidation of specimen, (4) application of hydraulic gradient.

Soil specimen was compacted in six layers. To achieve uniformity, the thickness of each layer was $5 \mathrm{~cm}$. Vaseline was
TABLE 2 | Testing program.

\begin{tabular}{|c|c|c|c|c|}
\hline $\begin{array}{l}\text { Test } \\
\text { series }\end{array}$ & Specimen & $\begin{array}{l}\text { Initial dry density, } \rho_{\mathrm{d}} \\
\left(\mathrm{g} / \mathrm{cm}^{3}\right)\end{array}$ & $\begin{array}{l}\text { Initial } \\
\text { FC (\%) }\end{array}$ & $\begin{array}{l}\text { Initial void } \\
\text { ratio, e }\end{array}$ \\
\hline \multirow[t]{3}{*}{1} & FC40-P300-D6 & 1.6 & 40 & 0.656 \\
\hline & FC40-P300-D7 & 1.7 & 40 & 0.558 \\
\hline & FC40-P300-D8 & 1.8 & 40 & 0.473 \\
\hline \multirow[t]{2}{*}{2} & FC20-P300-D7 & 1.7 & 20 & 0.558 \\
\hline & FC30-P300-D7 & 1.7 & 30 & 0.558 \\
\hline
\end{tabular}

smeared on inner walls of the permeameter chamber to prevent preferential flow along walls and to minimize friction effect between the walls and soil specimen. After specimen preparation, the pressure bladder was installed on the surface of specimen. A vertical stress of $25 \mathrm{kPa}$ was initially applied in the pressure bladder for sealing the permeameter cell.

Soil specimen was saturated in the permeameter cell. This stage was carried out using the vacuum saturation procedure [The Ministry of Water Resources of the People's Republic of China (SL237-1999), 1999; ASTM D467-11, 2012]. Initially, vacuum was applied to the soil specimen for $2 \mathrm{~h}$. Then, the inlet valve was connected to a de-aired water supply cylinder for deaired water gradually entering the specimen from the bottom inlet. This process lasted $\sim 6-8 \mathrm{~h}$ to ensure saturation quality. Generally, the $B$-value after saturation could be $>0.90$.

After saturation, the vertical stress of $300 \mathrm{kPa}$ was applied to the soil specimen and both the inlet and outlet of the permeameter cell were opened for the consolidation of soil specimen. This stage was completed when the readings of PWPs were stabilized.

After consolidation, hydraulic gradient was applied to the soil specimen by increasing water pressure at the inlet. The hydraulic gradient was increased step by step as suggested by Chang and Zhang (2011). The applied hydraulic gradient at each step was kept more than 10 min for observations. The readings of PWPs and the mass of outflow were also recorded. If obvious soil erosion was observed, the applied hydraulic gradient was further maintained constant until no soil loss was observed. When the applied hydraulic gradient reached a critical value, it was observed that the seepage velocity increased rapidly and a large amount of fine particles was flushed out of the soil specimen. At this moment, the suffusion test was terminated and the applied hydraulic gradient at this step was denoted as the failure hydraulic gradient, $i_{\mathrm{f}}$ (Luo et al., 2013b).

\section{TEST RESULTS AND DISCUSSION}

\section{Development of Seepage Velocity With the Applied Hydraulic Gradient}

Figure 3 shows the development of seepage velocity, $v$, with the applied hydraulic gradient, $i$, in all tests. The $v \sim i$ curves at different values of dry density and FC show a similar development pattern. At low values of hydraulic gradient, the seepage velocity increased approximately linearly with the hydraulic gradient. Meanwhile, the outflow was relatively clear 


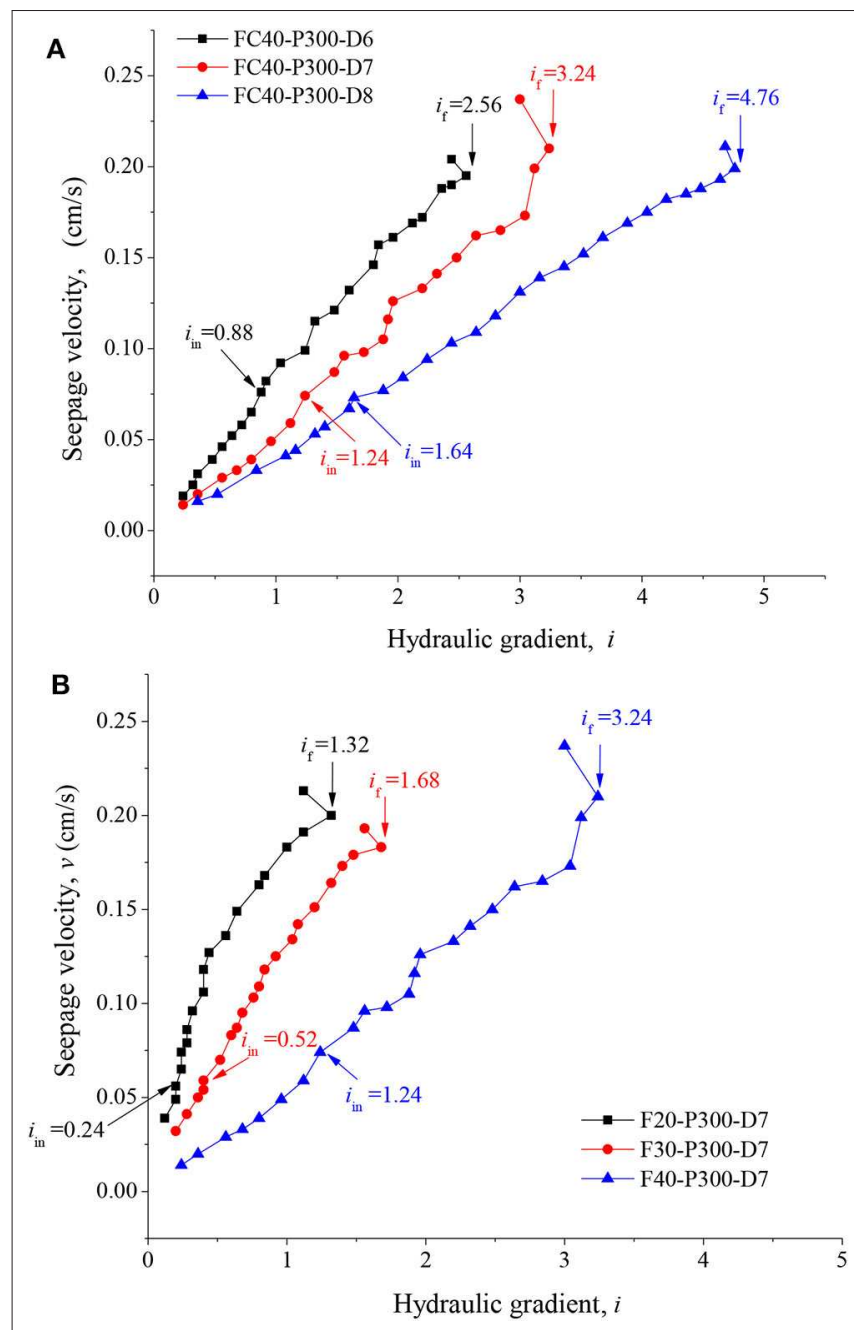

FIGURE 3 | Development of seepage velocity with the applied hydraulic gradient $(\mathbf{A})$ at various initial dry densities and $(\mathbf{B})$ at various initial FCs.

and it might indicate no occurrence of suffusion, consistent with the observations by Ke and Takahashi (2012), and Zou et al. (2013). As the hydraulic gradient increased to a certain value, fine particles began to be dislodged by seepage flow and the corresponding outflow became slightly turbid. This observation could be considered as a sign of the initiation of suffusion as suggested by Ke and Takahashi (2012), and Liang et al. (2017). The corresponding applied hydraulic gradient is termed as the initiation hydraulic gradient, $i_{\text {in }}$, in this study. Since the initiation of suffusion, the seepage velocity became to increase nonlinearly with the applied hydraulic gradient. At this stage, fine particles might begin to migrate from one location within the soil specimen to the voids of soil skeleton formed by coarse particles at other locations until the re-arrangement of all particles reached a new equilibrium. As the applied hydraulic gradient was increased further, the migration of fine particles resumed within the soil specimen. When the applied hydraulic gradient reached a certain high value (i.e., the failure hydraulic gradient), it was

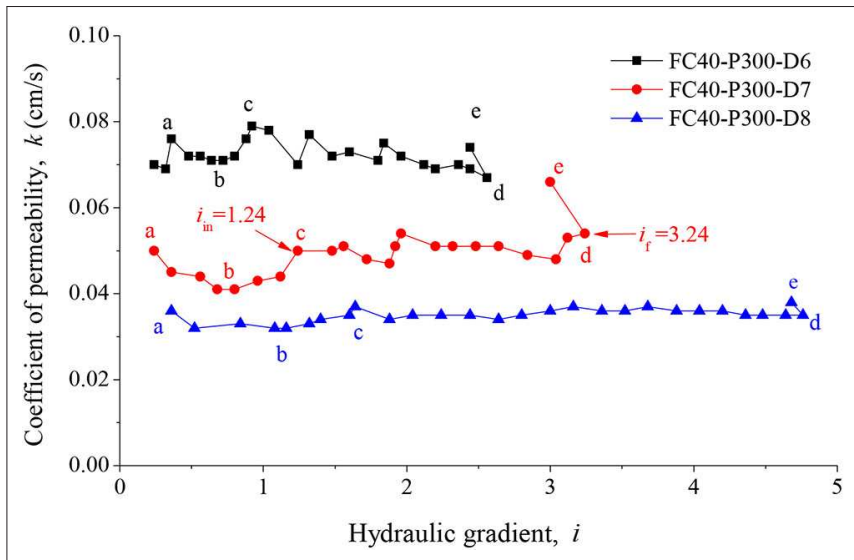

FIGURE 4 | Evolution of coefficient of permeability with the applied hydraulic gradient at various initial dry densities.

found that the seepage velocity increased rapidly and abundant fine particles were flushed out of the soil specimen. As a result, the applied hydraulic gradient could not be maintained anymore and the measured value dropped down suddenly. The outflow became very turbid and it indicated that the connected pore channels for fine particles had been formed among coarse particles. The effects of initial dry density and initial FC on the initiation and failure hydraulic gradients are discussed later.

\section{Evolution of Permeability With the Applied Hydraulic Gradient}

According to the Darcy's law, the coefficient of permeability can be derived from the data in Figure 3. For the suffusion tests, the change of coefficient of permeability is resulted from the migration of fine particles and hence some characteristics regarding the migration of fine particles within the soil specimen could be revealed by the evolution of permeability with the applied hydraulic gradient.

The evolution of permeability in three tests at various initial dry densities is shown in Figure 4. All curves show a similar variation in coefficient of permeability with the applied hydraulic gradient. Taking the test F40-P300-D7 as an example, the evolution of soil permeability with the increase in the applied hydraulic gradient can be divided into four stages. The first stage is the segment $a b$ as shown in Figure 4. During this stage, the coefficient of permeability was decreasing with the applied hydraulic gradient. Initially, the coefficient of permeability was $0.050 \mathrm{~cm} / \mathrm{s}$. As the applied hydraulic gradient increased, the coefficient of permeability dropped to $0.043 \mathrm{~cm} / \mathrm{s}$. This observation might indicate the migration of some movable fine particles within the soil specimen induced by seepage force. Some pores at a certain section in the soil specimen might be clogged by the eroded fine particles, thereby leading to a trend of gradual decrease in coefficient of permeability. The second stage is the segment $b c$ as the applied hydraulic gradient at the point $c$ is the initiation hydraulic gradient. During this stage, the coefficient of permeability increased from 0.043 to $0.051 \mathrm{~cm} / \mathrm{s}$. As the applied 
hydraulic gradient increased further in this stage, the seepage flow started to dredge the clogged pores and some fine particles began to flow away from the soil specimen, resulting in an increase of porosity within the soil specimen. Subsequently, the coefficient of permeability increased gradually. The third stage is the development of suffusion, i.e., the segment $c d$ with the applied hydraulic gradient at the point $d$ being the failure hydraulic gradient. During this stage, the coefficient of permeability decreased first from 0.051 to $0.047 \mathrm{~cm} / \mathrm{s}$, then increased to 0.054 $\mathrm{cm} / \mathrm{s}$, subsequently decreased again to $0.048 \mathrm{~cm} / \mathrm{s}$, and finally increased again to $0.054 \mathrm{~cm} / \mathrm{s}$. The alternate decrease and increase in the coefficient of permeability might indicate that the soil specimen was subjected to alternate clogging and dredging of soil pores correspondingly during the development of suffusion. In the last stage (i.e., the segment de), the coefficient of permeability increased suddenly when the applied hydraulic gradient was beyond the failure hydraulic gradient. Correspondingly, the rapid increase in seepage velocity was found from Figure 3. The significant increase in the coefficient of permeability was due to that a large amount of fine particles was flushed out of the soil specimen and hence the flow channels for both water and fine particles were formed within the soil specimen.

\section{Evolution of Local Hydraulic Gradients}

As shown in Figure 1B, pore water pressure transducers PWP2 PWP7 are distributed along the horizontal seepage flow path. Hence, local hydraulic gradients along the flow path can be obtained from the measurements of pore water pressure at points PWP2 PWP7. Figure 5 shows the evolution of local hydraulic gradients with the applied hydraulic gradient at the soil specimen of F40-P300-D7. In this figure, $i_{\mathrm{kj}}$ denotes the hydraulic gradient between points $\mathrm{k}$ and $\mathrm{j}$. For example, $i_{23}$ means the local hydraulic gradient between points 2 and 3 (i.e., PWP-2 and PWP-3, respectively). When the applied hydraulic gradient was lower than the initiation hydraulic gradient, all local hydraulic gradients were almost the same (Yao et al., 2009). On one hand, this means that the soil specimen was initially homogenous due to well specimen preparation. On the other hand, it is suggested that fine particles could not be driven by the seepage force at this stage and hence the internal structure of soil specimen was maintained intact. When the applied hydraulic gradient was higher than the initiation hydraulic gradient, the local hydraulic gradients at different locations became different from each other and hence the occurrence of uneven distribution of local hydraulic gradients in the soil specimen along the seepage flow path could be regarded as a sign of the initiation of suffusion. The uneven distribution of local hydraulic gradients became more obvious with the increasing applied hydraulic gradient. At the failure hydraulic gradient, the local hydraulic gradient at the middle section of soil specimen [i.e., $i_{45}$, was the largest, followed by that at the outlet section (i.e., $\left.i_{67}\right)$ ]. These two values were larger than the average value, which was equivalent to the corresponding applied hydraulic gradient across the soil specimen. The local hydraulic gradient at the inlet section i.e. $i_{23}$, was close to the average value and both $i_{34}$ and $i_{56}$ were smaller than the average value. The above observations might indicate that fine particles begin to migrate within the soil specimen under

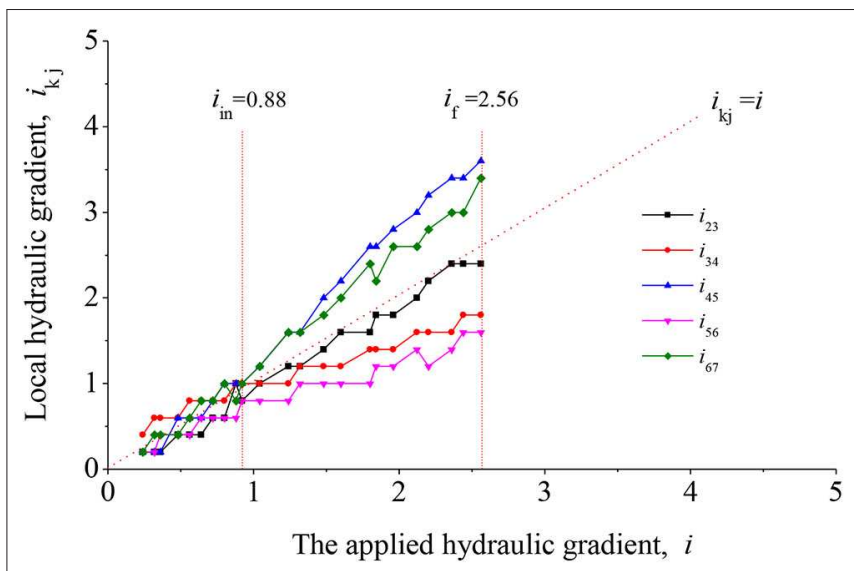

FIGURE 5 | Evolution of local hydraulic gradients within the soil specimen of FC40-P300-D6 with the hydraulic gradient applied across the soil specimen.

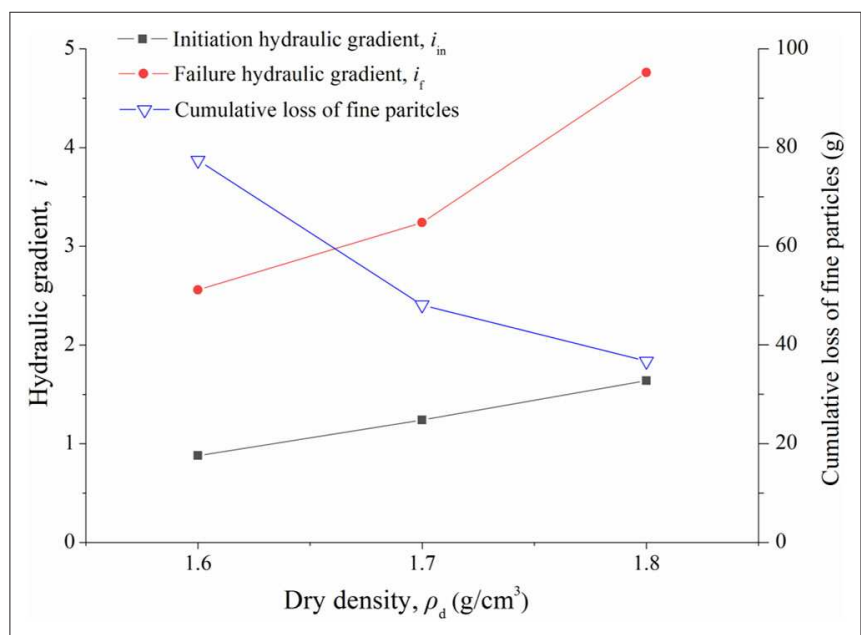

FIGURE 6 | Effect of initial dry density on initiation and failure hydraulic gradients as well as cumulative loss of fine particles.

the higher seepage force and hence the internal structure was altered, leading to non-uniform local permeability, and hence uneven distribution of local hydraulic gradients along the seepage flow path.

\section{Effect of Initial Dry Density}

As shown in Figure 3, at a given hydraulic gradient, the seepage velocity decreased with the initial dry density. This was mainly due to the decrease of coefficient of permeability with the initial dry density (see Figure 4). Figure 6 shows the effect of initial dry density on initiation and failure hydraulic gradients as well as the cumulative loss of fine particles. As expected, both hydraulic gradients increased with the initial dry density due to the smaller size of pores resulting from higher dry density (Zhang et al., 2009; Zhu et al., 2016; Chen et al., 2019). Smaller pores could increase the erosion resistance of soils and make it more difficult for fine particles to migrate. Hence, higher dry density led to a smaller cumulative weight of eroded fine particles as shown in this figure. 


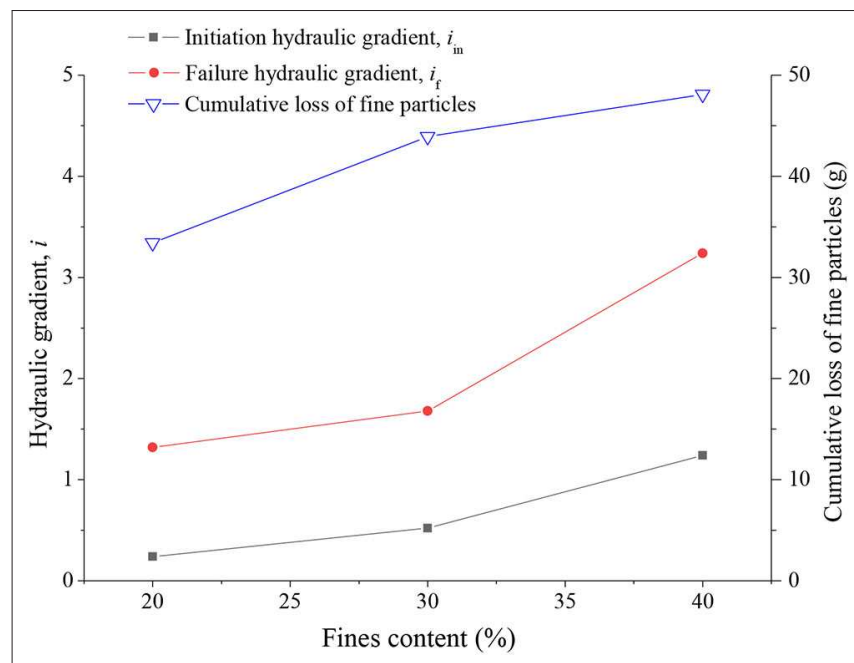

FIGURE 7 | Effect of initial FC on initiation and failure hydraulic gradients as well as cumulative loss of fine particles.

\section{Effect of Initial FC}

Figure 7 shows the effect of initial FC on suffusion behavior. Both initiation and failure hydraulic gradients increased with the value of FC. For the soil specimen with a smaller FC, most fine particles were "freely" filled in the voids of soil skeleton formed by coarse particles and they were not involved in the load transfer chains within the soil mass subjected to loading. Hence, the fine particles in the soil specimen with a smaller FC might be moved easily by seepage force, thereby leading to a low initiation hydraulic gradient (Seghir et al., 2014). As the value of FC became larger, some fine particles were involved in the load transfer chains. Thus, the initiation and failure hydraulic gradient increased with the FC. When FC was $40 \%$, most fine particle might be fixed in the load transfer chains and hence it led to the initiation hydraulic gradient higher than 1 even subjected to the horizontal seepage flow. Possibly due to the increased amount of movable fine particles, the cumulative loss of fine particles increased with the initial FC.

\section{CONCLUSIONS}

Two series of tests on horizontal seepage-induced suffusion in gap-graded cohesionless soils were conducted in this study and the following main conclusions can be drawn.

1. Before the initiation of suffusion, the seepage velocity increased approximately linearly with the hydraulic gradient. But their relationship became non-linear since the initiation

\section{REFERENCES}

ASTM D287-11 (2012). Standard Practice for Classification of Soils for Engineering Purposes (Unified Soil Classification System). Annual Book of ASTM Standards. ASTM International, West Conshohocken, PA. of suffusion. At the failure hydraulic gradient, the seepage velocity increased rapidly.

2. The evolution of soil permeability with the increase in the applied hydraulic gradient can be divided into four stages. After the initiation of suffusion, alternate decrease and increase in the coefficient of permeability was observed, indicating that the soil specimen was subjected to alternate clogging and dredging of soil pores by the movable fine particles.

3. When the applied hydraulic gradient was higher than the initiation hydraulic gradient, the local hydraulic gradients became unevenly distributed along the flow path and this observation could be regarded as a sign of the initiation of suffusion.

4. Both initiation and failure hydraulic gradients increased with initial dry density and initial fines content. The higher initial dry density led to a smaller cumulative weight of eroded fine particles but the larger initial fc showed an opposite effect.

\section{DATA AVAILABILITY STATEMENT}

The datasets generated for this study are available on request to the corresponding author.

\section{AUTHOR CONTRIBUTIONS}

GD and RC contributed conception and design of the study. RC has taken primary responsibility for communication with the journal and editorial office during the submission process, throughout peer review, and during publication. L-LZ wrote the first draft of the manuscript. K-XS performed the experimental investigation. LL and Z-LZ organized the database. All authors contributed to the article and approved the submitted version.

\section{FUNDING}

This work was supported by the National Key Research and Development Program of China (grant no. 2017YFC0404803); the National Natural Science Foundation of China (grant no. 51578196); the Shenzhen Science and Technology Innovation Commission (grant no. JCYJ20170811160740635); the Independent Research Fund of State Key Laboratory of Simulation and Regulation of Water Cycle in River Basin (grant no. SKL2020ZY09); and the IWHR Research and Development Support Program (grant no. GE0145B562017). 
Chang, D. S., and Zhang, L. M. (2011). A stress-controlled erosion apparatus for studying internal erosion in soils. Geotech. Test. J. 34, 579-589. doi: $10.1520 / \mathrm{GTJ} 103889$

Chang, D. S., and Zhang, L. M. (2012). Critical hydraulic gradients of internal erosion under complex stress states. J. Geotech. Geoenviron. Eng. 139, 1454-1467. doi: 10.1061/(ASCE)GT.1943-5606.0000871

Chang, D. S., and Zhang, L. M. (2013). Extended internal stability criteria for soils under seepage. Soils Found. 53, 569-583. doi: 10.1016/j.sandf.2013.06.008

Chang, D. S., Zhang, L. M., Xu, Y., and Huang, R. Q. (2011). Field testing of erodibility of two landslide dams triggered by the 12 May wenchuan earthquake. Landslides 8, 321-332. doi: 10.1007/s10346-011-0256-X

Chen, S. S., Lin, H., Mi, Z. K., Miao, Z., and Mei, S. A. (2019). Experimental study on permeability and its influencing factors for sandy gravel of dashixia dam. Chin. J. Geotechn. Eng. 41, 26-31. doi: 10.11779/CJGE201901002

Deng, G., Chen, R., Liu, J., Shu, K. X., Yu, S., Zhou, Z. L., et al. (2017). A Large Deformation Completely Closed Visual Measuring Device for Horizontal Latent Corrosion. GuangDong: CN107192811A.

Fell, R., Wan, C. F., Cyganiewicz, J., and Foster, M. (2003). Time for development of internal erosion and piping in embankment dams. J. Geotechn. Geoenviron. Eng. 129, 307-314. doi: 10.1061/(ASCE)1090-0241(2003)129:4(307)

Foster, M., Fell, R., and Spannagle, M. (2000). The statistics of embankment dam failures and accidents. Can. Geotechn. J. 37, 1000-1024. doi: 10.1139/t00-030

Horikoshi, K., and Takahashi, A. (2015). Suffusion-induced change in spatial distribution of fine fractions in embankment subjected to seepage flow. Soils Found. 55, 1293-1304. doi: 10.1016/j.sandf.2015.09.027

Hosseini, S. M. M. M., and Pachideh, V. (2018). A new physical model for studying flow direction and other influencing parameters on the internal erosion of soils. Geotech. Test. J. 42:20170301. doi: 10.1520/GTJ20170301

Indraratna, B., Israr, J., and Rujikiatkamjorn, C. (2015). Geometrical method for evaluating the internal instability of granular filters based on constriction size distribution. J. Geotech. Geoenviron. Eng. 141:04015045. doi: 10.1061/(ASCE)GT.1943-5606.0001343

Indraratna, B., Nguyen, V. T., and Rujikiatkamjorn, C. (2011). Assessing the potential of internal erosion and suffusion of granular soils. J. Geotech. Geoenviron. Eng. 137, 550-554. doi: 10.1061/(ASCE)GT.1943-5606.0000447

Kang, P., Hong, L., Fazhi, Y., Quanle, Z., Xiao, S., and Zhaopeng, L. (2020). Effects of temperature on mechanical properties of granite under different fracture modes. Eng. Fract. Mech. 226:106838. doi: 10.1016/j.engfracmech.2019.106838

Ke, L., and Takahashi, A. (2012). Strength reduction of cohesionless soil due to internal erosion induced by one-dimensional upward seepage flow. Soils Found. 52, 698-711. doi: 10.1016/j.sandf.2012.07.010

Ke, L., and Takahashi, A. (2014). Experimental investigations on suffusion characteristics and its mechanical consequences on saturated cohesionless soil. Soils Found. 54, 713-730. doi: 10.1016/j.sandf.2014.06.024

Kenney, T. C., Chahal, R., Chiu, E., Ofoegbu, G. I., Omange, G. N., and Ume, C. A. (1985). Controlling constriction sizes of granular filters. Can. Geotech. J. 22, 32-43. doi: 10.1139/t85-005

Kenney, T. C., and Lau, D. (1985). Internal stability of granular filters. Can. Geotech. J. 22, 215-225. doi: 10.1139/t85-029

Liang, Y., Yeh, T. C. J., Wang, J., Liu, M., Zha, Y., and Hao, Y. (2019). Onset of suffusion in upward seepage under isotropic and anisotropic stress conditions. Eur. J. Environ. Civil Eng. 23, 1520-1534. doi: 10.1080/19648189.2017. 1359110

Liang, Y., Zeng, C., Wang, J. J., Liu, M. W., Yeh, T. C. J., and Zha, Y. Y. (2017). Constant gradient erosion apparatus for appraisal of piping behavior in upward seepage flow. Geotech. Test. J. 40, 630-642. doi: 10.1520/GTJ20150282

Luo, Y., Luo, B., and Xiao, M. (2019). Effect of deviator stress on the initiation of suffusion. Acta Geotech. 15, 1607-1617. doi: 10.1007/s11440-019-00859-x

Luo, Y., Nie, M., and Xiao, M. (2017). Flume-scale experiments on suffusion at bottom of cutoff wall in sandy gravel alluvium. Can. Geotech. J. 54, 1716-1727. doi: 10.1139/cgj-2016-0248

Luo, Y. L., Qiao, L., Liu, X. X., Zhan, M. L., and Sheng, J. C. (2013a). Hydromechanical experiments on suffusion under long-term large hydraulic heads. Nat. Hazards 65, 1361-1377. doi: 10.1007/s11069-012-0415-y

Luo, Y. L., Wu, Q., Zhan, M. L., Sheng, J. C., and Wang, Y. (2013b). Hydromechanical coupling experiments on suffusion in sandy gravel foundations containing a partially penetrating cut-off wall. Nat. Hazards 67, 659-674. doi: 10.1007/s11069-013-0596-Z
Marot, D., Rochim, A., Nguyen, H. H., Bendahmane, F., and Sibille, L. (2016). Assessing the susceptibility of gap-graded soils to internal erosion: proposition of a new experimental methodology. Nat. Hazards 83, 365-388. doi: 10.1007/s11069-016-2319-8

Mehdizadeh, A., Disfani, M. M., Evans, R., and Arulrajah, A. (2017). Progressive internal erosion in a gap-graded internally unstable soil: mechanical and geometrical effects. Int. J. Geomech. 18:04017160. doi: 10.1061/(ASCE)GM.1943-5622.0001085

Moffat, R., Fannin, R. J., and Garner, S. J. (2011). Spatial and temporal progression of internal erosion in cohesionless soil. Can. Geotech. J. 48, 399-412. doi: 10.1139/T10-071

Moffat, R. A., and Fannin, R. J. (2006). A large permeameter for study of internal stability in cohesionless soils. Geotech. Test. J. 29, 273-279. doi: 10.1520/GTJ100021

Moraci, N., Mandaglio, M. C., and Ielo, D. (2014). Analysis of the internal stability of granular soils using different methods. Can. Geotech. J. 51, 1063-1072. doi: 10.1139/cgj-2014-0006

Ouyang, M., and Takahashi, A. (2015). Influence of initial fines content on fabric of soils subjected to internal erosion. Can. Geotech. J. 53, 299-313. doi: 10.1139/cgj-2014-0344

Peng, K., Liu, Z., Zou, Q., Wu, Q., and Zhou, J. (2020a). Mechanical property of granite from different buried depths under uniaxial compression and dynamic impact: an energy-based investigation. Powder Technol. 362, 729-744. doi: 10.1016/j.powtec.2019.11.101

Peng, K., Shi, S., Zou, Q., Zhang, Y., and Tan, G. (2020b). Gas permeability characteristics and energy evolution laws of gas-bearing coal under multi-level stress paths. Nat. Resourc. Res. doi: 10.1007/s11053-020-09636-0. [Epub ahead of print].

Peng, K., Wang, Y., Zou, Q., Liu, Z., and Mou, J. (2019a). Effect of crack angles on energy characteristics of sandstones under a complex stress path. Eng. Fract. Mech. 218:106577. doi: 10.1016/j.engfracmech.2019.106577

Peng, K., Zhou, J., Zou, Q., and Song, X. (2020c). Effect of loading frequency on the deformation behaviours of sandstones subjected to cyclic loads and its underlying mechanism. Int. J. Fatigue 131:105349. doi: 10.1016/j.ijfatigue.2019.105349

Peng, K., Zhou, J., Zou, Q., and Yan, F. (2019b). Deformation characteristics of sandstones during cyclic loading and unloading with varying lower limits of stress under different confining pressures. Int. J. Fatigue 127, 82-100. doi: 10.1016/j.ijfatigue.2019.06.007

Peng, M., and Zhang, L. M. (2012). Breaching parameters of landslide dams. Landslides 9, 13-31. doi: 10.1007/s10346-011-0271-y

Richards, K. S., and Reddy, K. R. (2012). Experimental investigation of initiation of backward erosion piping in soils. Géotechnique 62, 933-942. doi: 10.1680/geot.11.P.058

Rochim, A., Marot, D., Sibille, L., and Thao Le, V. (2017). Effects of hydraulic loading history on suffusion susceptibility of cohesionless soils. J. Geotech. Geoenviron. Eng. 143:04017025. doi: 10.1061/(ASCE)GT.1943-5606.0001673

Salehi Sadaghiani, M. R., and Witt, K. J. (2011). Experimental identification of mobile particles in suffusible non cohesive soils. Eur. J. Environ. Civil Eng. 15, 1155-1165. doi: 10.1080/19648189.2011.9714846

Sato, M., and Kuwano, R. (2015). Suffusion and clogging by onedimensional seepage tests on cohesive soil. Soils Found. 55, 1427-1440. doi: 10.1016/j.sandf.2015.10.008

Seghir, A., Benamar, A., and Wang, H. (2014). Effects of fine particles on the suffusion of cohesionless soils. Exp. Model. Transport Porous Media 103, 233-247. doi: 10.1007/s11242-014-0299-2

Skempton, A. W., and Brogan, J. M. (1994). Experiments on piping in sandy gravels. Geotechnique 44, 449-460. doi: 10.1680/geot.1994.44.3.449

Song, L. H., Huang, Q., Yan, D., and Mei, G. X. (2018). Experimental study on effect of hydraulic gradient on permeability of clay. Chin. J. Geotech. Eng. 40, 1635-1641. doi: 10.11779/CJGE201809009

The Ministry of Water Resources of the People's Republic of China (SL2371999) (1999). Specification of Seepage and Seepage Deformation test for Coarse Grained Soil (SL237-058-1999). Beijing: China Water Power Press.

Wan, C. F., and Fell, R. (2008). Assessing the potential of internal instability and suffusion in embankment dams and their foundations. J. Geotech. Geoenviron. Eng. 134, 401-407. doi: 10.1061/(ASCE)1090-0241(2008)134: 3(401) 
Wang, S., Chen, J. S., Luo, Y. L., and Sheng, J. C. (2014). Experiments on internal erosion in sandy gravel foundations containing a suspended cutoff wall under complex stress states. Nat. Hazards 74, 1163-1178. doi: $10.1007 / \mathrm{s} 11069-014-1243-\mathrm{Z}$

Wang, Y. X., Shan, S. B., Zhang, C., and Guo, P. P. (2019). Seismic response of tunnel lining structure in a thick expansive soil stratum. Tunn. Undergr. Space Technol. 88, 250-259. doi: 10.1016/j.tust.2019.03.016

Xu, Y., and Zhang, L. M. (2009). Breaching parameters for earth and rockfill dams. J. Geotech. Geoenviron. Eng. 135, 1957-1970. doi: 10.1061/(ASCE)GT.1943-5606.0000162

Yang, R., Xiao, P., and Qi, S. (2019). Analysis of slope stability in unsaturated expansive soil: a case study. Front. Earth Sci. 7:292. doi: 10.3389/feart.2019.00292

Yao, Z. X., Zhou, J., and Zhang, G. (2009). Meso-experimental research on piping mechanism in sandy soils. Rock Soil Mech. 30, 1604-1610. doi: 10.16285/j.rsm.2009.06.046

Yuan, B., Sun, M., Wang, Y., Zhai, L., Luo, Q., and Zhang, X. (2019b). Full 3D displacement measuring system for 3D displacement field of soil around a laterally loaded pile in transparent soil. Int. J. Geomech. 19:04019028. doi: 10.1061/(ASCE)GM.1943-5622.0001409

Yuan, B., Sun, M., Xiong, L., Luo, Q., Pradhan, S. P., and Li, H. (2020). Investigation of $3 \mathrm{D}$ deformation of transparent soil around a laterally loaded pile based on a hydraulic gradient model test. J. Build. Eng. 28:101024. doi: 10.1016/j.jobe.2019.101024

Yuan, B., Xiong, L., Zhai, L., Zhou, Y., Chen, G., Gong, X., et al. (2019a). Transparent synthetic soil and its application in modeling of soil-structure interaction using optical system. Front. Earth Sci. 7:276. doi: 10.3389/feart.2019.00276

Zhang, J. F., Ding, P. Z., Zhang, W., and Hu, Z. J. (2009). Studies of permeability and seepage deformation characteristics of cushion material for shuibuya concrete faced rockfill dam. Rock Soil Mech. 30, 3145-3150. doi: 10.16285/j.rsm.2009.10.023

Zhang, L. M., Xu, Y., Jia, J. S., and Zhao, C. (2011). Diagnosis of embankment dam distresses using bayesian networks. Part I. Global-level characteristics based on a dam distress database. Can. Geotech. J. 48, 1630-1644. doi: 10.1139/t11-069

Zhao, Y., Wang, Y., Wang, W., Tang, L., Liu, Q., and Cheng, G. (2019). Modeling of rheological fracture behavior of rock cracks subjected to hydraulic pressure and far field stresses. Theor. Appl. Fract. Mech. 101, 59-66. doi: 10.1016/j.tafmec.2019.01.026

Zhong, C., Le, V. T., Bendahmane, F., Marot, D., and Yin, Z. Y. (2018). Investigation of spatial scale effects on suffusion susceptibility. J. Geotech. Geoenviron. Eng. 144:04018067. doi: 10.1061/(ASCE)GT.1943-5606.00 01935

Zhu, Y. J., Peng, J., and Chen, Q. (2016). Contact scouring tests on sandy gravel and cohesive soil. Chin. J. Geotech. Eng. 38, 92-97. doi: 10.11779/CJGE2016S2015

Zou, Y. H., Chen, Q., and He, C. R. (2013). A new large-scale plane-strain permeameter for gravelly clay soil under stresses. KSCE J. Civil Eng. 17, 681-690. doi: 10.1007/s12205-013-0217-0

Conflict of Interest: The authors declare that the research was conducted in the absence of any commercial or financial relationships that could be construed as a potential conflict of interest.

Copyright (c) 2020 Deng, Zhang, Chen, Liu, Shu and Zhou. This is an open-access article distributed under the terms of the Creative Commons Attribution License (CC $B Y)$. The use, distribution or reproduction in other forums is permitted, provided the original author(s) and the copyright owner(s) are credited and that the original publication in this journal is cited, in accordance with accepted academic practice. No use, distribution or reproduction is permitted which does not comply with these terms. 